\title{
Harderian gland of flying and non-flying birds: morphological, histological, and histochemical studies
}

\author{
Rasha R. Beheiry ${ }^{1 *}$ D, Sozan A. Ali ${ }^{1}$, Mohamed Aref $^{2}$ and Hassan Emam²
}

\begin{abstract}
Background: The aim of the present study is to describe the morphological and histological features of Harderian gland (HG) in long-legged wadding bird (ibis) and different domestic birds (duck, goose, and pigeon). The HG of forty adult male and female from the four avian species constituted the material of the study.

Result: The HG extended from the optic nerve to the rostral part of the eyeball presents two extremities, one posterior and other anterior, from which the excretory duct was arisen. Between two extremities of the gland, middle groove is present in case of duck and geese, while middle isthmus is present in case of ibis. In pigeon, the gland appeared pointed oval in shape. Microscopically, the HG was multilobular; each lobule was composed of secretory acini that were lined by a single layer of columnar epithelium. In all studied birds, a single duct located centrally with an irregular lumen. In goose, there were crypts along the duct while in duck, the central lumen had villi-like folds projected into the central canal of the tubules. In ibis, the irregular lumen was narrow and elongated while in pigeon, the gland had a central cavity that collected the secretion from tubules arranged radially around the cavity; also, the gland mainly contained both acidic and neutral mucopolysaccharides.
\end{abstract}

Conclusion: This work revealed that the histological structure of HG in the four avian species showed characteristic features and thus explained the relationship between their habits and behavior on the structure of this gland.

Keywords: Harderian gland, Morphology, Histology

\section{Background}

The studies on the accessory organs of the eye are essential for understanding of normal eye physiology. These organs include the eyebrows, eyelids, eyelashes, conjunctival sac, lacrimal apparatus, and extrinsic muscles of the eye. Among the accessory organs of the eye are the eyelids that have great importance in understanding the pathogenesis of eye diseases, the conjunctiva-associated lymphoid tissue (CALT), the HG, and the lacrimal gland (LG) (Fix \& Arp, 1989).

The HG was first described by Johann Jacob Harder in 1694, identified also as paraorbital glands. The gland is

\footnotetext{
* Correspondence: rasharagab2006@yahoo.com

'Department of Histology and Cytology, Faculty of Veterinary Medicine,

Zagazig University, Zagazig, Sharkia 44511, Egypt

Full list of author information is available at the end of the article
}

found in most terrestrial species having nictitating membrane. This gland is also present in amphibians and avian species (fowl, duck, pheasants, turkeys, cardinal), in rudimentary form or is absent in primates, and not found in carnivores (Sakai, 1981).

It is known that the secretion of HG lubricates the nictitating membrane and or the cornea (Baccari, Minucci, \& Di Matteo, 1993; Payne, 1994; Sakai, 1981). Also, it is a source of growth factors (Baccari et al., 1993) and immune response (Mobini, 2012; Ohshima \& Hiramatsu, 2002), but in some species, they are so modified as to be primarily associated with nasal, vomeronasal, and salivary functions (Djaridane, Simmonneaux, \& Klosen, 1999; Payne, 1994; Rehorek, Baker, Hutchinson, Bruce, \& F., 2006; Sakai, 1981). 
The HG and LG in birds are considered as a part of the head associated lymphatic tissue (HALT) (Shirama, Satoh, Kitamura, \& Yamada, 1996). According to Boydak and Aydin (2009) in goose, the type of secretion in the HG is mucous, and the mode of secretion is apocrine.

Payne (1994) mentioned that the irregularly shaped HG covers most of the posteromedial surface of the eye from the optic nerve to the point where the gland's narrow duct passes beneath the proximal attachments of the superior and inferior oblique muscles. The duct of the gland passes forwards around the eye to open into the inferomedial portion of the conjunctival sac deep to the nictitating membrane.

The fore mentioned author added that, in bi-lobed HG, there is a groove in which an extra-ocular muscle, the pyramidalis oculi, is situated. It often divides the gland into two lobes which are not distinct from each other in some birds, such as the duck and pelican; it is almost hemispherical with a shallow concave face abutting onto the eyeball and a deeply convex surface adjoining the orbit wall.

Burns (1992) noted that, in fowl, the HGs are relatively large and more developed than the lacrimal gland. The latter author added that the HG is the lymph epithelial organ.

In geese, Boydak and Aydin (2009) revealed that the HG is multilobular tubulo-alveolar and pour its secretion into a wide lumen which is lined by columnar epithelial cells. In the Capercaillie, Klećkowska-Nawrot, and Goździewska- Harłajczuk, K., Kowalczyk, A., I., Łukaszewicz, E. I., and Nowaczyk, R. I. (2016a) mentioned that large number of lymphocytes detected in the HG may indicate their exposure to various pathogens and indicate better resistance.

The aim of the present study is to demonstrate and compare the normal anatomical and histological structure of HG in four avian species: ducks and geese (as an example of non-flying birds) and ibis and pigeons (as an example of flying birds). The knowledge of normal histological structure of HG is important and required for the diagnosis and treatment of ocular diseases.

\section{Materials and methods}

\section{Collection of samples}

The current investigations were carried out on forty adult healthy birds of both sexes of each following species: domestic ducks (Anas platyrhynchus), domestic goose (Anser anser domesticus), domestic pigeon (Columba livia domestica), and long-legged wadding bird as ibis (Bubulcus ibis) according to the ethics of AVMA guidelines to minimize pain and was approved by the Research Ethics Committee of the Faculty of Veterinary Medicine, Zagazig University, Zagazig, Egypt. The birds were taken from different farms in Sharkia Governorate, and an informed oral and written consents were obtained from farm owners; then, the birds were kept in our laboratory and give them tap water ad libitum. Ten birds for each species were anesthetized with ketamine and euthanized using of $\mathrm{CO}_{2}$ gas. The birds were sacrificed by decapitation, and their heads were removed as soon as possible; then, the HGs were injected directly by a fixative (10\% formalin) solution into the orbital cavity; then, the whole heads were preserved in the same fixative.

\section{Tissue preparation}

\section{For macro morphology}

The HG and their associated excretory ducts within the eyeball, the muscles were carefully dissected after removing of the lower jaw, cranial bone, and brain. Each specimen was divided into two equal parts by a sagittal line between the orbital cavities. Then, HG was dissected morphologically from the vicinity of the orbit ventromedial to the eyeball then prepared for photography and prepared for macro morphology (during their dissection, the position, shape, and color were noted). The nomenclatures used along the course of the present work were those adopted by Nomina Anatomica Veterinaria (2012).

\section{For morphometry}

The average length, width, and thickness of the gland were recorded. These parameters were measured by a plastic ruler; then, the results were analyzed by SPSS version 25 (SPSS IBM Corp, Armonk, NY). Descriptive statistics by mean \pm SD were used to describe data. Simple bar graph was used to depict the results.

\section{For light microscopy examination}

The processing and staining methods were performed according to Suvarna, Layton, and Bancroft (2018). Briefly, the specimens were dissected out, cleaned rapidly of any adherent connective tissue then immediately fixed in $10 \%$ buffered neutral formalin. Then, they were processed and embedded in paraffin. Using rotary microtome, paraffin sections of $5 \mu \mathrm{m}$ were obtained and subjected for staining with the following stains:

- Harris's hematoxylin and eosin (H\&E) stain for studying the general structure.

- Masson trichrome stain for demonstration of collagen and muscle fibers.

- Periodic Acid Schiff (PAS) technique to detect neutral glycosaminoglycans.

- Alcian blue pH (2.5) for detecting acidic glycosaminoglycans.

The stained sections were examined with standard light microscopy, and photographs were taken at 
Department of Histology and Cytology, Faculty of Veterinary Medicine, Zagazig University.

\section{Results}

\section{Macroscopic observation}

The eyes in all of the different adult birds have anterior and posterior canthus and bounded by upper and lower eye lids (Fig. 1). The HGs of the all examined adults birds were present in the vicinity of the orbit ventromedial to the eyeball (Fig. 2).

All HGs in different species were extended from the optic nerve posteriorly to the rostral part of the eyeball. So two extremities were present: one posterior extremity near to the optic nerve and other anterior or rostral one near to the rostral part of the eyeball from which the excretory duct was arisen. Between two extremities of the gland, middle groove is present in case of duck and goose while middle isthmus is present in case of ibis which was covered by one of the extraocular muscle (pyramidalis oculi) (Figs. 2 and 3).

The gland appeared oval flat with an irregular outline in addition in pigeon; the gland appeared pointed oval and has two extremities: one anterior pointed extremity from which excretory duct arisen while other broad posterior extremity directed towards the optic nerve (Figs. 2 and 3).

All glands were dissected easily from the periorbital fascia, covered by thin thread fibrous tissues, and may be found in the vicinity of the orbit or loosely adherence to the posterior part of the eyeball. The surfaces of the glands of the all examined birds which were facing the periorbital fascia were convex while the surfaces of the glands which were facing the eyeball were concave. The

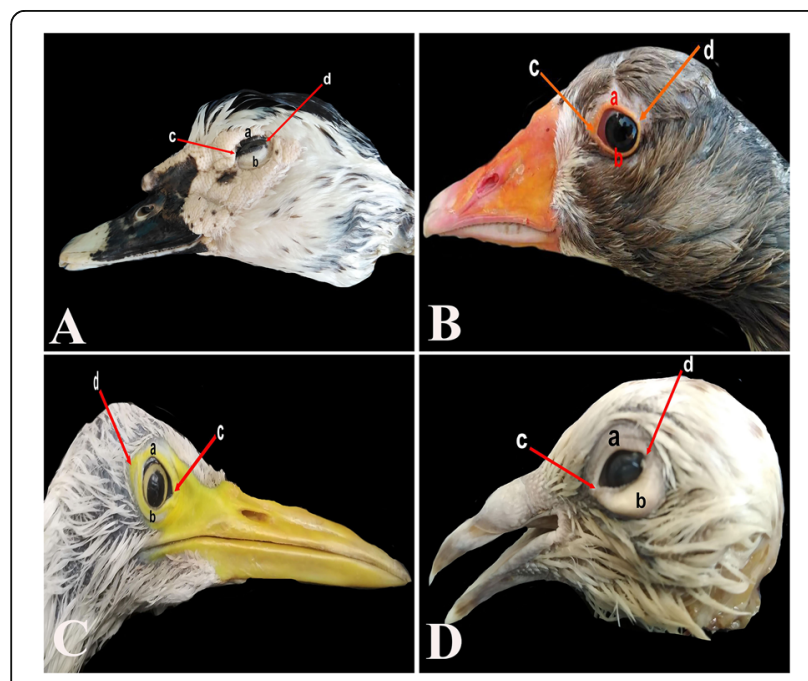

Fig. 1 A photomacrograph of head showing external features of the eye, upper eye lid (a), lower eye lid (b), anterior canthus (c), and posterior canthus (d) in $\operatorname{duck}(\mathbf{A})$, goose $(\mathbf{b})$, ibis (c), and pigeon (d)

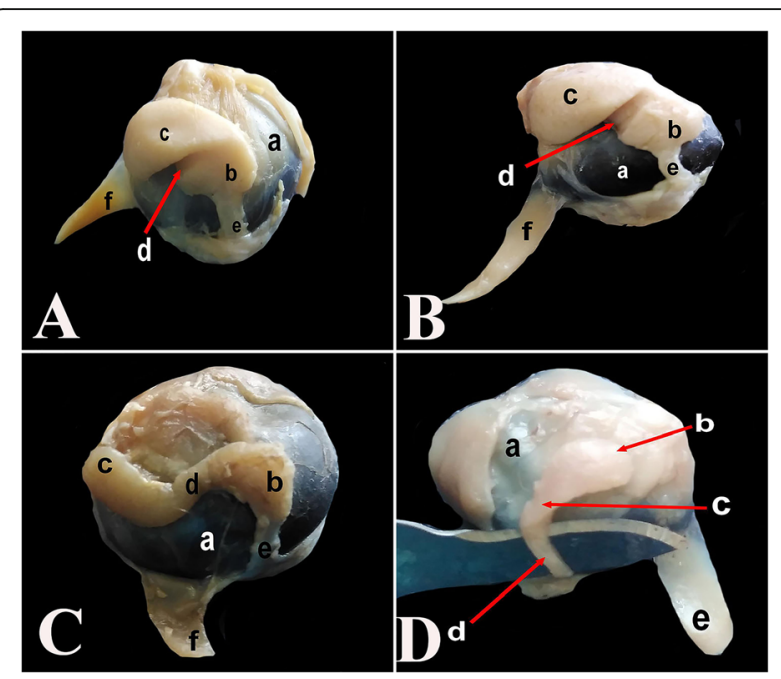

Fig. 2 A photomacrograph of the eye showing anatomical dissection of the $\mathrm{HG}$, eyeball (a), anterior extremity (b), posterior extremity $(\mathbf{c})$, middle groove $(\mathbf{d})$, excretory duct (e), and extraocular muscle (pyramidalis oculi) (f) in $\operatorname{duck}(\mathbf{A})$, goose (b), ibis (c), and pigeon (d)

color of the glands was ranged from pinkish white to reddish brown. One excretory duct of the all examined glands arisen from anterior extremity then passed to open in the medial part of the conjunctival membrane (Figs. 2 and 3).

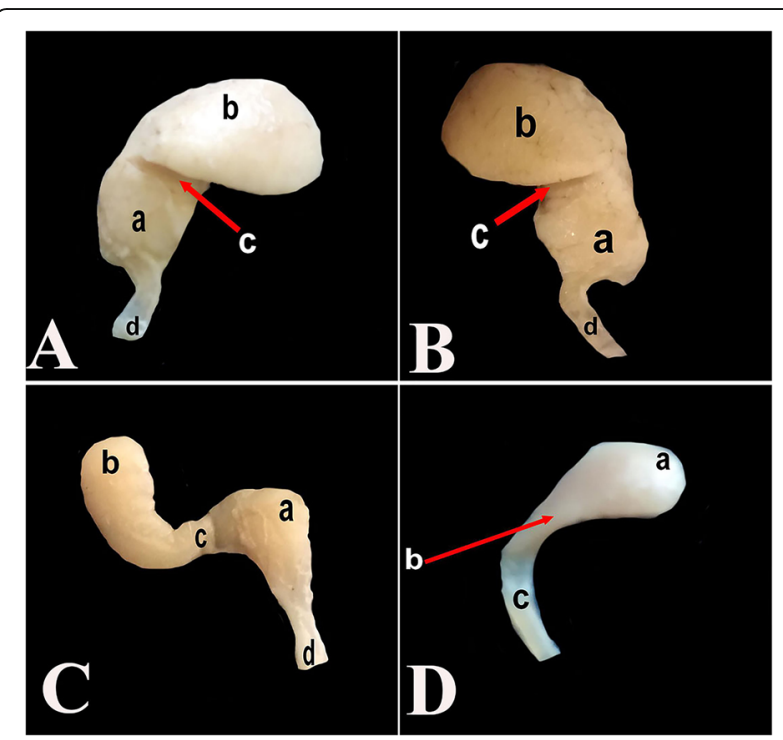

Fig. 3 A photomacrograph of isolated HG showing anterior extremity (a), posterior extremity (b), middle groove (c), and excretory duct (d) in duck (a) and goose (B). Isolated HG of ibis showing anterior extremity (a), posterior extremity (b), middle isthmus (c), and excretory duct (d) in C. Isolated HG of pigeon showing posterior broad extremity (a), anterior pointed extremity (b), and excretory duct (c) in $\mathbf{D}$ 


\section{Morphometrical studies}

Descriptive statistics of different dimensions (length, width of both extremities, and thickness) of HG in adult duck and goose, adult ibis, and adult pigeon were recorded in Tables 1, 2, and 3, respectively.

The mean of the all length in duck and goose together, ibis, and pigeon were recorded as $1.65,1.57$, and 0.71 $\mathrm{cm}$, respectively. The mean of the widest part of the gland were $0.95 \mathrm{~cm}$ in duck and goose, $0.45 \mathrm{~cm}$ in ibis, and $0.43 \mathrm{~cm}$ in pigeon. While the mean thickness of the gland was $0.39 \mathrm{~cm}$ in duck and goose, $0.15 \mathrm{~cm}$ in ibis and $0.18 \mathrm{~cm}$ in pigeon are as shown in Figs. 4, 5, and 6 .

\section{Histological observation}

In all studied birds, the HG was surrounded by thin connective tissue capsule. The capsule mainly formed of collagen fibers that contained blood vessels. The connective tissue septa raised from the capsule with blood vessels and nerves and divided the parenchyma into lobules of different sizes, which appeared as polygonal zones in case of duck containing a central canal. Each lobule consisted of secretory acini which separated by little amount of connective tissue. In all studied birds, a single duct located centrally with an irregular lumen. In geese, there were crypts along the duct, and solitary lymphoid nodules were near the crypts (Fig. 7). In pigeon and ibis, the glandular acini were at the peripheral region of the lobules and continued with the tubular portions of the secretary units; in addition, the pointed and broad extremities were observed (Fig. 8).

The glands were compound tubulo-alveolar and emptied into a wide central lumen. In duck, the central lumen had villi-like folds that were branched and interconnected, lined with simple columnar epithelium with vacuolated cytoplasm, and project into the central canal of the tubules. While in geese, the central lumen was irregular containing crypts, and they were lined by columnar epithelium which was darkly stained. The ductal epithelium was surrounded by myoepithelial cells. The gland had an excretory duct (Fig. 9).

In ibis, the irregular lumen was narrow and elongated while in pigeon, the gland had a central cavity that

Table 1 Descriptive statistics of different dimensions (cm) (length, width of both extremities, and thickness) of HG in adult duck and goose

\begin{tabular}{llll}
\hline Parameter & Mean \pm SD & Minimum & Maximum \\
\hline Length of HG & $1.65 \pm 0.047$ & 1.50 & 1.80 \\
$\begin{array}{l}\text { Width of HG } \\
\text { (anterior extremity) }\end{array}$ & $0.95 \pm 0.108$ & 0.80 & 1.10 \\
$\begin{array}{l}\text { Width of HG } \\
\text { (posterior extremity) }\end{array}$ & $0.89 \pm 0.074$ & 0.80 & 1.00 \\
Thickness of HG & $0.39 \pm 0.057$ & 0.30 & 0.50 \\
\hline
\end{tabular}

Table 2 Descriptive statistics of different dimensions (cm) (length, width, and thickness) of HG in adult ibis

\begin{tabular}{|c|c|c|c|}
\hline Parameter & Mean \pm SD & Minimum & Maximum \\
\hline Whole length of $\mathrm{HG}$ & $1.57 \pm 0.11$ & 1.50 & 1.80 \\
\hline $\begin{array}{l}\text { Length of ant extremity of } \\
\mathrm{HG}\end{array}$ & $0.76 \pm 0.08$ & 0.70 & 0.90 \\
\hline $\begin{array}{l}\text { Length of post extremity } \\
\text { of HG }\end{array}$ & $0.51 \pm 0.03$ & 0.50 & 0.60 \\
\hline $\begin{array}{l}\text { Length of isthmus of } \\
\mathrm{HG}\end{array}$ & $0.30 \pm 0.000$ & 0.30 & 0.3 \\
\hline $\begin{array}{l}\text { Width of ant extremity of } \\
\mathrm{HG}\end{array}$ & $0.37 \pm 0.11$ & 0.30 & 0.60 \\
\hline $\begin{array}{l}\text { Width of post extremity of } \\
\text { HG }\end{array}$ & $0.45 \pm 0.07$ & 0.4 & 0.6 \\
\hline $\begin{array}{l}\text { Width of isthmus of } \\
\text { HG }\end{array}$ & $0.27 \pm 0.11$ & 0.2 & 0.5 \\
\hline Thickness of HG & $0.15 \pm 0.07$ & 0.1 & 0.3 \\
\hline
\end{tabular}

collected the secretion from tubules arranged radially around the cavity. In the two species, a large number of lymphocytes were densely aggregated in the lobules underneath the lining epithelium; also, these cells were distributed in the interstitial connective tissue that surrounding the acini and tubules (Fig. 10).

In the four avian species, the secretory acini were lined by single layer of columnar epithelium with highly vacuolated cytoplasm and spherical basaly located nucleus and surrounded by flat myoepithelial cells; their nuclei were elongated which located between the basal surface of the epithelial cells and the basement membrane. In duck, the peripheral secretory acini were elongated and tortuous while in geese, the peripheral secretory acini were lined with high columnar epithelium that were lightly stained in contrast to the cells of central duct that were darkly stained (Fig. 11). Histological structure of HG and its duct in male and female was the same in the four avian species.

In PAS-stained sections in duck, goose, ibis, and pigeon, the positive reaction was demonstrated in the centrally located cells of glandular epithelium of tubules and glandular epithelium of acini. Also, the neutral mucosubstances were detected in the connective tissue septa between the secretory end pieces and in the

Table 3 Descriptive statistics of different dimensions (cm) (whole length, width, and thickness) of $\mathrm{HG}$ in adult pigeon

\begin{tabular}{llll}
\hline Parameter & Mean \pm SD & Minimum & Maximum \\
\hline Whole length of HG & $0.71 \pm 0.057$ & 0.60 & 0.80 \\
Width of HG & $0.43 \pm 0.082$ & 0.30 & 0.60 \\
Thickness of HG & $0.18 \pm 0.078$ & 0.10 & 0.30 \\
\hline
\end{tabular}




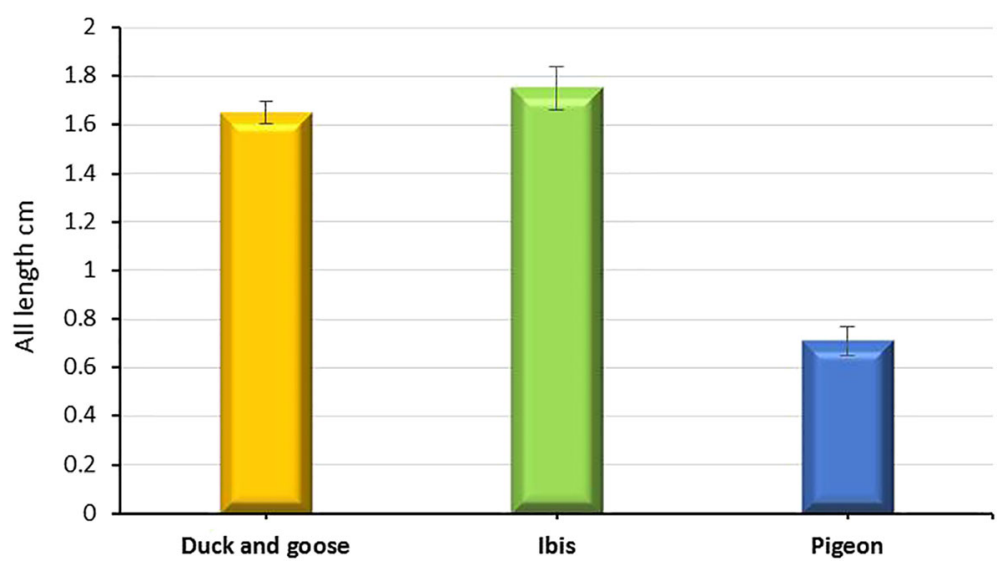

Fig. 4 Descriptive statistics of mean \pm SD of whole length of HG in adult duck, goose, ibis, and pigeon

excretory duct (Fig. 12). In alcian blue stained sections, high degree of alcianophilia in the centrally located cells. The glandular epithelium of secretory units and the epithelial cells that lined ducts had positive reaction (Fig. 13).

\section{Discussion}

In this study, the HGs of the all examined adults birds were present in the vicinity of the orbit ventromedial to the eyeball. These findings were supported by those of Wight, Mackenzie, Rothwell, and Burns (1971a) in domestic fowl; Kozlu, Bozkurt, Altunay, and Sari (2010) in osprey; and Mobini (2012 and 2014) in chicken, while Klećkowska-Nawrot, Goździewska-Harłajczuk, Kowalczyk, Łukaszewicz, and Nowaczyk (2016a) in Capercaillies observed the gland was laid in the orbit, lateral to the caudal portion of the interorbital septum and medial to the caudal third of the eyeball.

The shape and excretory duct of HGs of the all examined pigeons were appeared oval flat with an irregular outline; meanwhile, Klećkowska-Nawrot, GoździewskaHarłajczuk, Kowalczyk, Łukaszewicz, and Nowaczyk (2016b) recorded that the HG, in the common pheasant, was wider in the proximal and distal part. The common pheasant had more elongated lobes of the HG than in the hybrid. The HG in domestic fowl was appeared irregular in shape (Payne, 1994; Wight, Mackenzie, et al., 1971a).

The measurements of HGs of the all examined domestic ducks were in a line with macromorphometry mentioned by Brobby Sr (1972) who observed the HG measured $1.7 \mathrm{~cm}$ long, $1.5 \mathrm{~cm}$ broad, and $0.5 \mathrm{~cm}$ thick. It has two ducts open on the deep surface of the nictitating membrane.

Our research revealed that the HGs of the all examined adults birds have a single excretory duct arisen from anterior extremity then passed to open in the medial part of the conjunctival membrane. This is in line with the results were given by Wight, Burns, Rothwell, and Mackenzie (1971b) in domestic fowl, Kozlu et al. (2010) in osprey, Burns (1974), and Boydak and Aydin

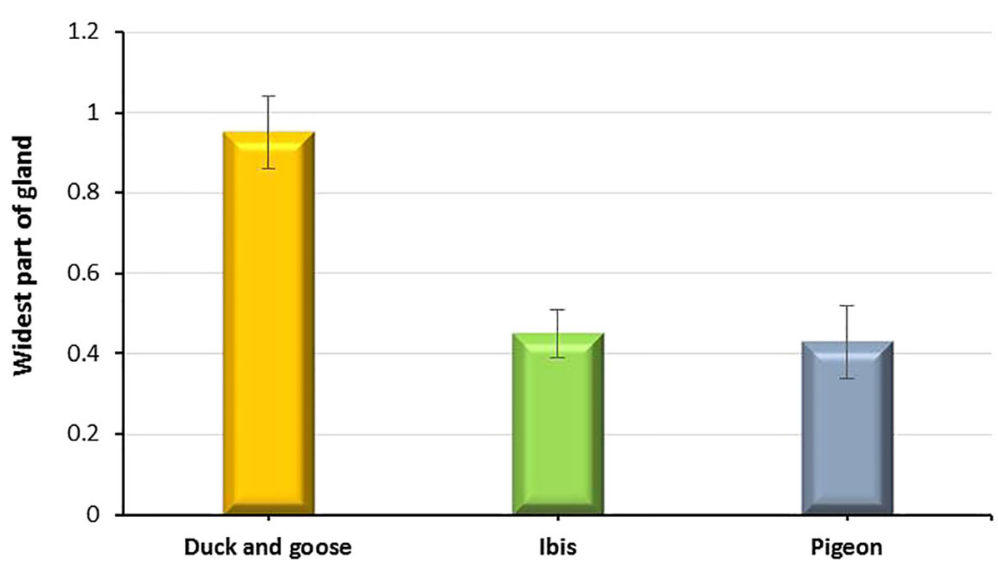

Fig. 5 Descriptive statistics of mean \pm SD of widest part of HG in adult duck, goose, ibis, and pigeon 


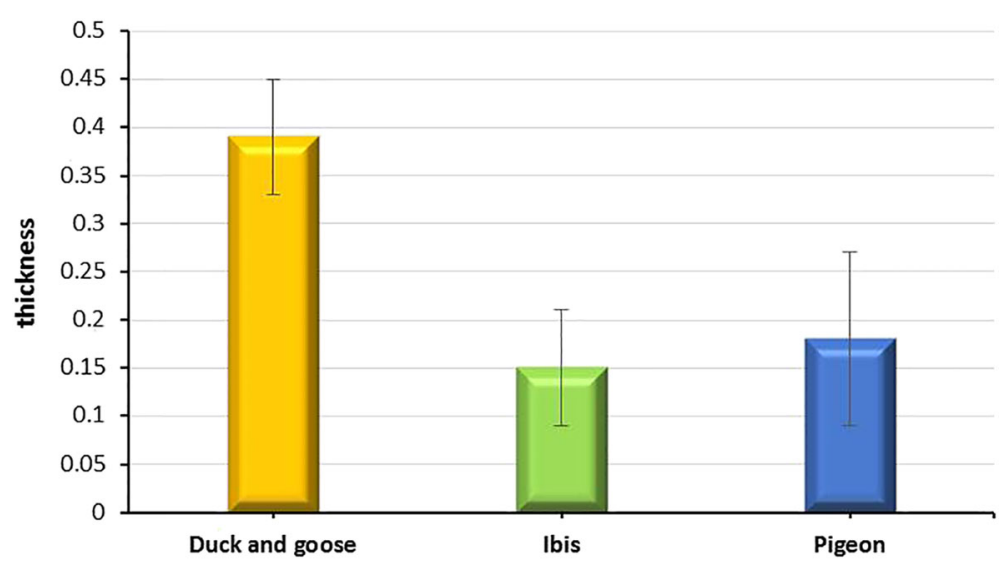

Fig. 6 Descriptive statistics of mean \pm SD of thickness of HG in adult duck, goose, ibis, and pigeon

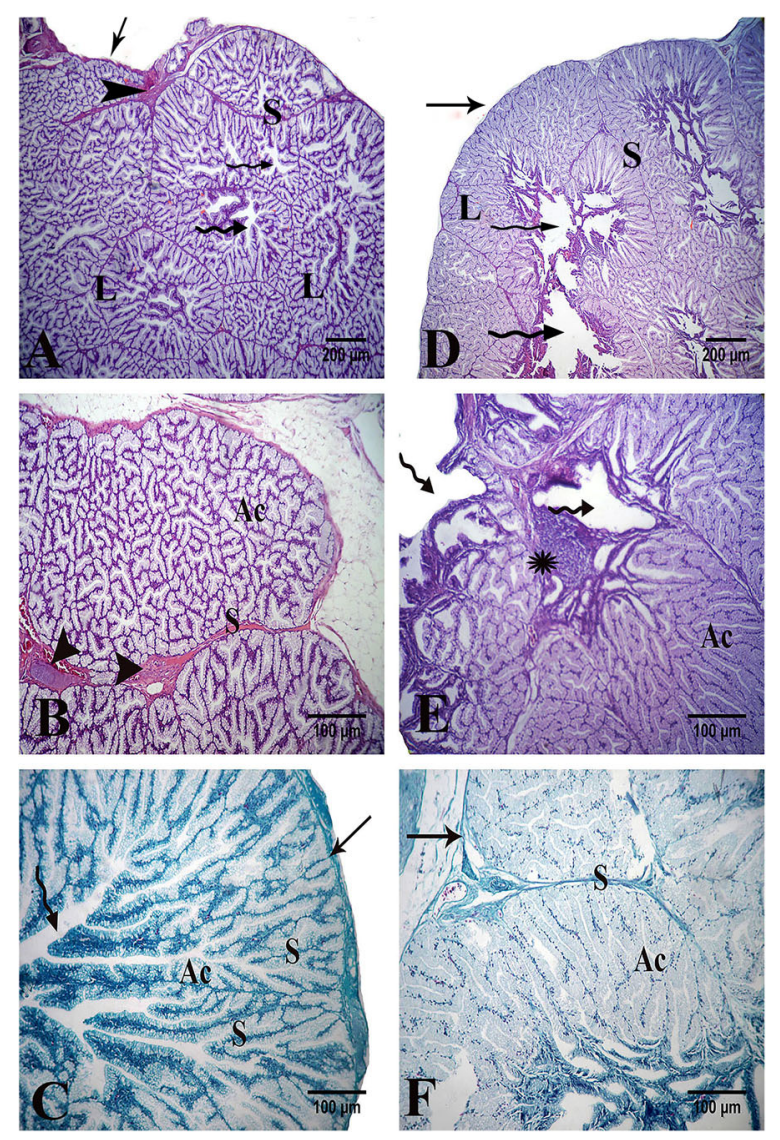

Fig. 7 Light micrograph of the HG of $\operatorname{duck}(\mathbf{A}, \mathbf{B}, \mathbf{C})$ and goose (D, E, F) showed the lobules (L) formed from secretory acini (AC) and covered by capsule (arrow) containing blood vessels (red arrow heads), septa (S) containing blood vessel and nerve fiber (black arrow heads), lymphatic nodule in goose (star), and irregular lumen of duct (zigzag arrow). Stain, H\&E in (A, B, D, E) and Masson trichrome in $(\mathbf{C}, \mathbf{F})$
(2009) in geese. That was not in agreement with the statements of Brobby Sr (1972) in duck who stated that the duck HG had two secretory ducts but Burns (1974), employing careful dissection and India ink injection, could find only one.

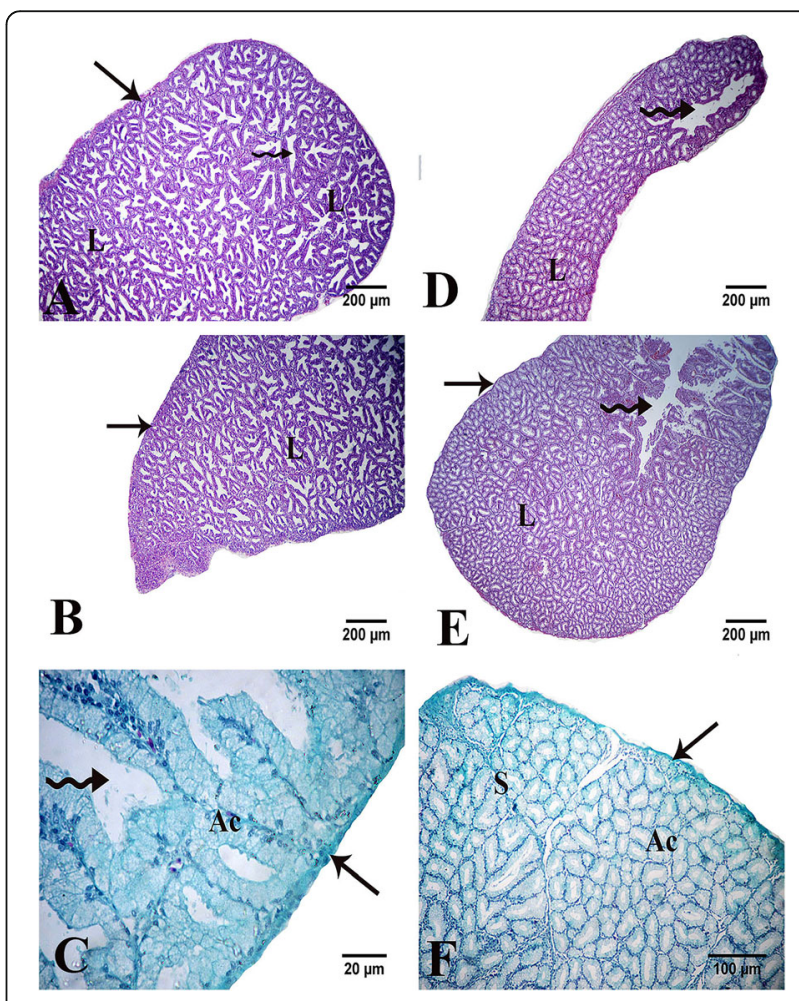

Fig. 8 Light micrograph of the HG of ibis (A, B, C) and pigeon (D, E, F) showed the lobules ( $L$ ) formed from secretory acini (AC) and covered by capsule (arrow), septa (S), and irregular lumen of duct (zigzag arrow). Note the broad extremity of the gland in $\mathbf{A}$ and $\mathbf{E}$ and pointed extremity in $\mathbf{B}$ and $\mathbf{D}$. Stain, H\&E in $\mathbf{A}, \mathbf{B}, \mathbf{D}$, and $\mathbf{E}$ and Masson trichrome in $\mathbf{C}$ and $\mathbf{F}$ 


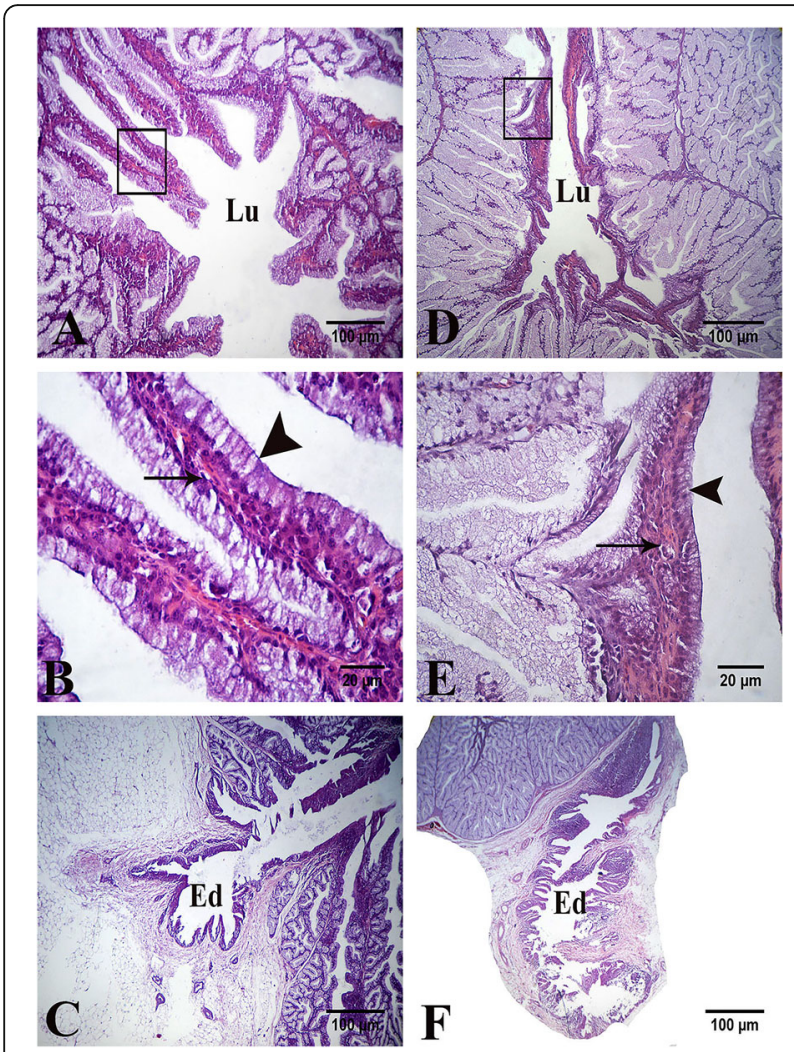

Fig. 9 Light micrograph of the $H G$ of $\operatorname{duck}(\mathbf{A}, \mathbf{B}, \mathbf{C})$ and goose (D, E, F). The intratubular villi-like folds project into the lumen (Lu) of centrally situated canal (A). The higher magnification to the rectangle of $\mathbf{A}$ represents the lining epithelium of central duct was simple columnar epithelium (arrow head) and surrounded by myoepithelial cells (arrow) (B) and the excretory duct (Ed) in $\mathbf{C}$. The irregular central lumen was contained crypts (D). The higher magnification to the rectangle of $\mathbf{D}$ represents the lining epithelium of central duct was simple columnar epithelium darkly stained (arrow head) and surrounded by myoepithelial cells (arrow) in $\mathbf{E}$. The excretory duct (Ed) in $\mathbf{F}$. Stain, H\&E

The surfaces of the bilobed glands of the all examined birds which was facing the periorbital fascia were convex while the surfaces of the glands which facing the eyeball were concave. This observation was in accordance with Payne (1994) in birds.

Between two extremities of the gland, middle groove is present in case of duck and geese while middle isthmus is present in case of ibis which was covered by one of the extraocular muscle (pyramidalis oculi). This observation was in agreement with Payne (1994) in birds.

Burns and Maxwell (1979) in the fowl, turkey, and duck mentioned that a single duct left the anterior tip of the HG to open into the conjunctival sac at the base of the nictitating membrane. In the fowl, the course of this duct may be followed by a row of pigmented spots on either side or its single opening located by a circle of spot.

The functions of the gland were involved in the protection of the eye against bright light and played role in

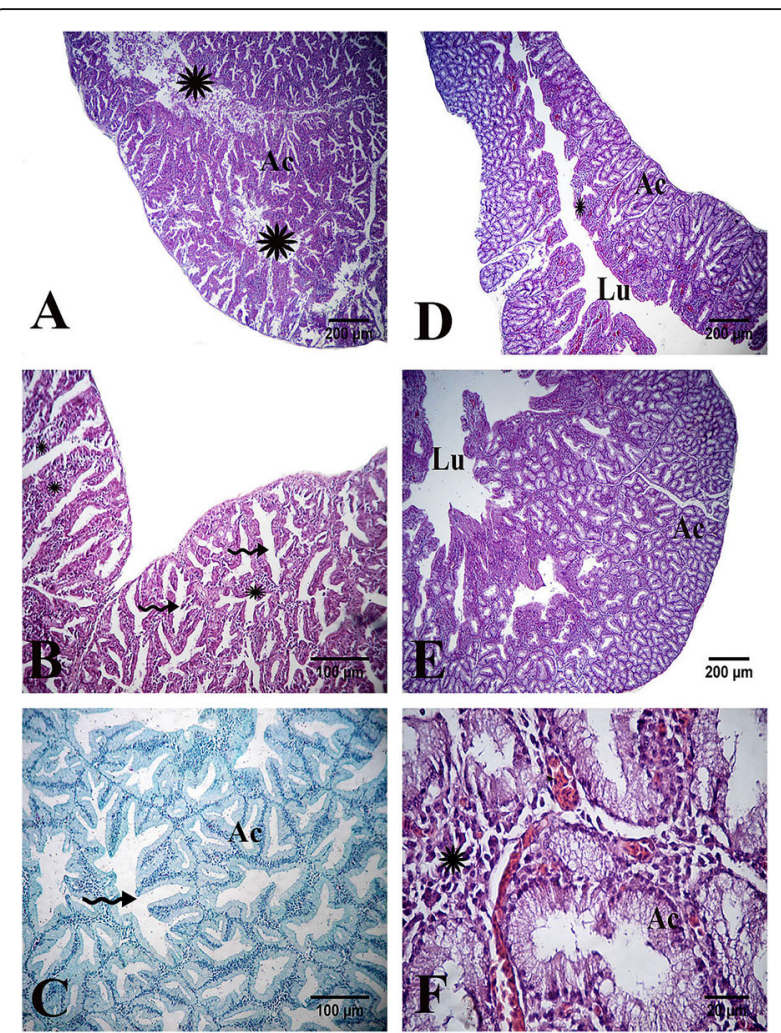

Fig. 10 Light micrograph of the HG of ibis $(\mathbf{A}, \mathbf{B}, \mathbf{C})$ and pigeon (D, E, F) showed the secretory acini (Ac), lumen of collecting duct (Lu), irregular lumina (zigzag arrows), and note the distribution of lymphocytes in the lobule (star). Stain, H\&E in $\mathbf{A}, \mathbf{B}, \mathbf{D}, \mathbf{E}$, and $\mathbf{F}$ and Masson trichrome in $\mathbf{C}$

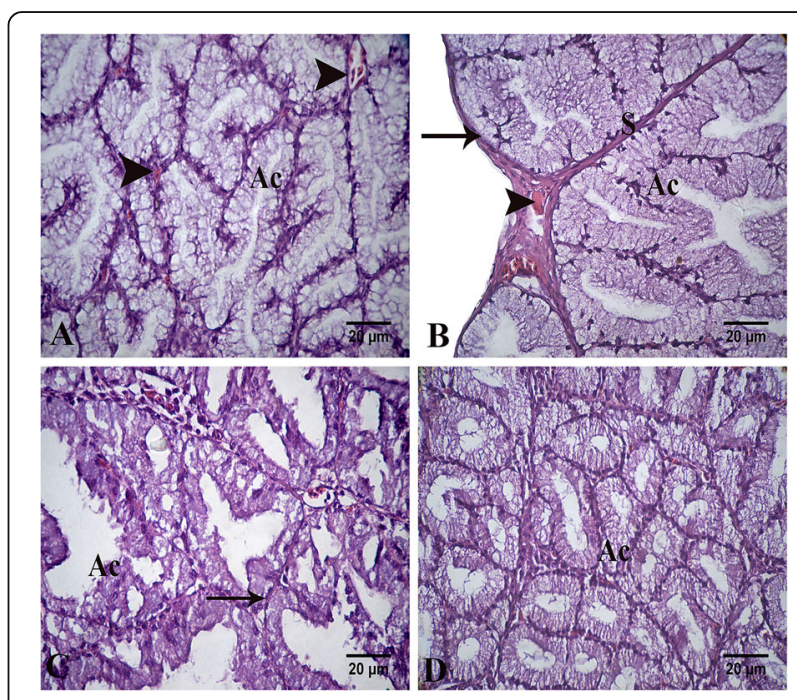

Fig. 11 Light micrograph of the HG of duck (A), goose (B), ibis (C), and pigeon (D). Secretory acini (Ac), capsule (arrow), blood vessel and capillaries in the capsule and in interstitial tissue (arrow heads), and myoepithelial cell (arrow). Stain, H\&E 

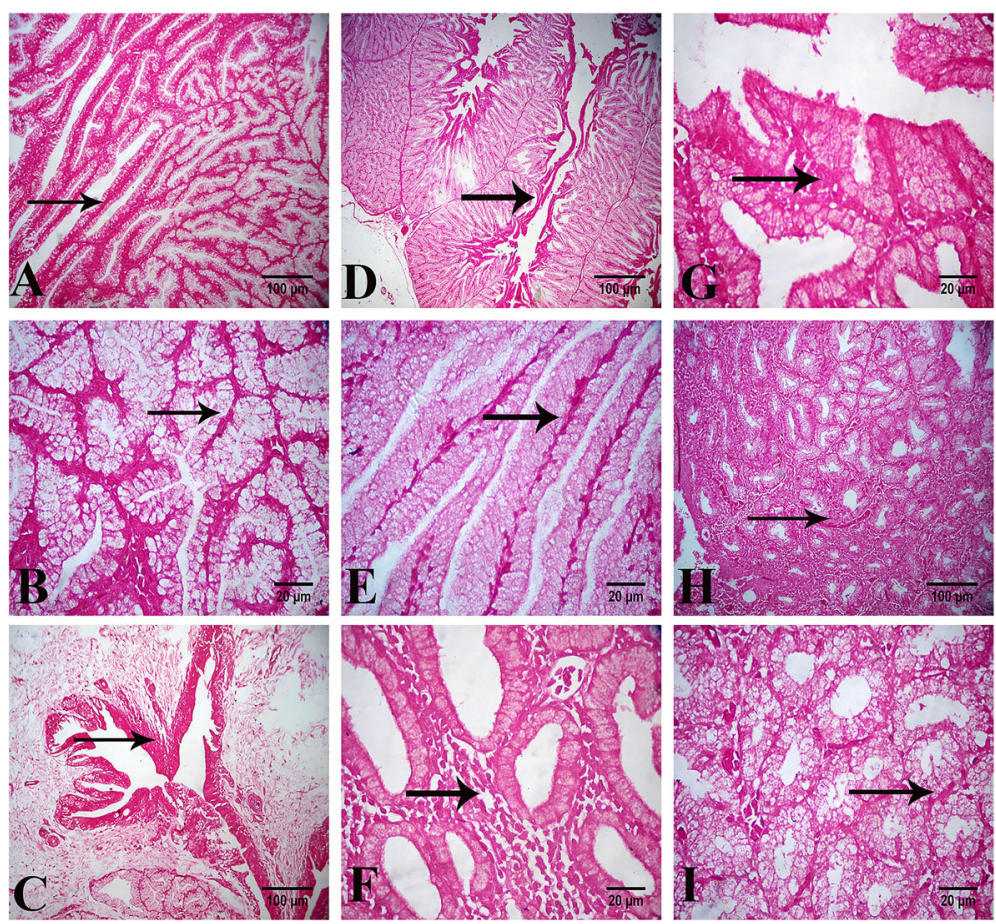

Fig. 12 Light micrograph of the HG of duck $(\mathbf{A}, \mathbf{B}, \mathbf{C})$, goose $(\mathbf{D}, \mathbf{E})$, ibis $(\mathbf{F}, \mathbf{G})$, and pigeon $(\mathbf{H}, \mathbf{I})$. Positive reaction was observed in the centrally located cells of glandular epithelium of tubules and glandular epithelium of acini, in the connective tissue septa between the secretory end pieces and in the excretory duct with periodic acid Schiff reagent. Stain, PAS

photodynamic process (Funasaka, Yoshioka, \& Fujise, 2010). The gland may have endocrine function (Pradidarcheep et al., 2003). In avian eye, the gland had great role in response to infection and vaccination (Zakeri \& Kashefi, 2011).

The HG was a peripheral lymphoepithelial organ (secondary immune organ) which, together with the spleen, the bursa of Fabricius and the cecal tonsils formed a system of avian organs that determined both general and local immunity (Fix, Arp, \& H., 1991; Shirama et al., 1996). It also represents an important part of the immune barrier CALT (Khan et al., 2007; Payne, 1994).

Our investigation revealed that there were no differences between male and female and that was in agreement with that reported by Oliveira, Telles, Oliveira et al. (2006) Khan et al. (2007); Ginkel, Tang, Gulley, and Toro (2009); Boydak and Aydin (2009); and Mobini (Mobini, 2012; Mobini, 2014).
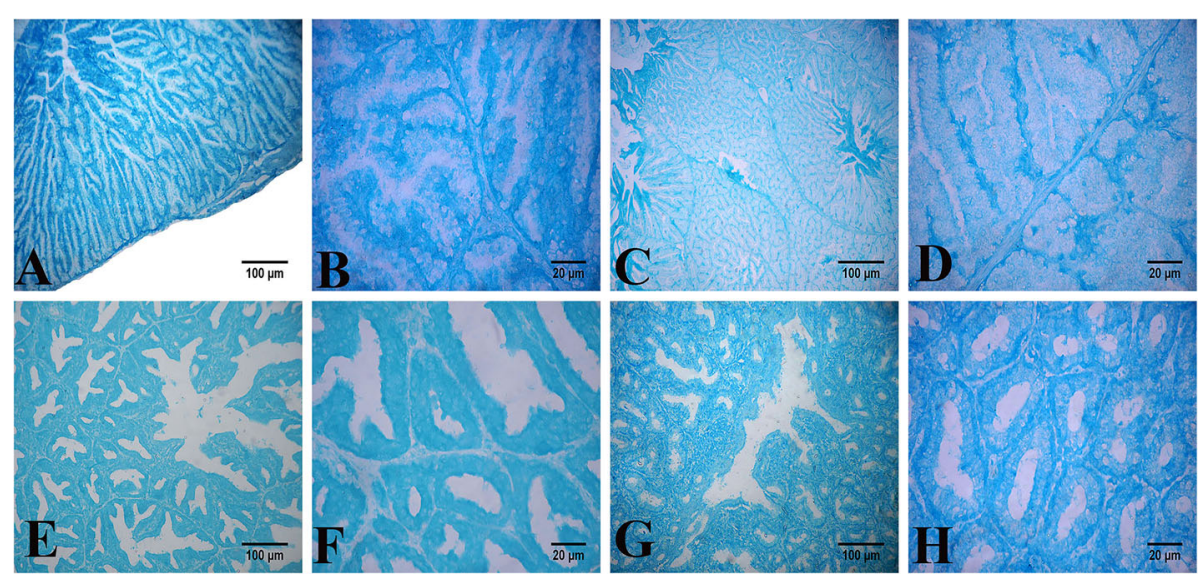

Fig. 13 Light micrograph of the $\mathrm{HG}$ of $\operatorname{duck}(\mathbf{A}, \mathbf{B})$, goose $(\mathbf{C}, \mathbf{D})$, ibis $(\mathbf{E}, \mathbf{F})$, and pigeon $(\mathbf{G}, \mathbf{H})$. Positive reaction in centrally located cells of ducts and the glandular epithelium of secretory units with alcian blue. Stain, alcian blue $\mathrm{pH} 2.5$ 
The present work revealed that the histological examination of the HG of all studied birds as was mentioned by Burns and Maxwell (1979), Maxwell, Rothwell, and Burns (1986) in domestic fowl and turkey, and Boydak and Aydin (2009) in goose. The gland was surrounded by a connective tissue capsule that was compound tubuloacinar and lined with simple columnar cells. In our study, central collecting duct was lined with simple columnar secretory epithelium in the HG of all studied birds; these results were similar to that of Burns and Maxwell (1979) in fowl, duck, and turkey, Altunay and Kozlu (2004) in ostrich, Boydak and Aydin (2009) in geese, Kozlu et al. (2010), Kozlu and Altunay (2011) in quail, and Mobini (2012) in chicken, while Brobby Sr (1972) mentioned that the gland was compound tubular in domestic duck.

Myoepithelial cells with darkly stained flat nucleus were noticed; it was surrounding the secretary cells. The presence of these cells was mentioned by Cacho, Gallego, Felices, and Bascuas (1991) and Mobini (2012) in the HG of chicken and by Altunay and Kozlu (2004) in ostrich.

Histochemically, the epithelial cells of the secretary units and ducts were positively reacted by alcian blue ( $\mathrm{pH}$ 2.5) and thus indicating the presence of acid mucopolysaccharides. The current histochemical finding has been reported previously by Wight, Burns, et al. (1971b) in domestic fowl; Boydak and Aydin (2009) in domestic geese; Klećkowska-Nawrot, Goździewska-Harłajczuk, Barszcz, and Kowalczyk (2015) in ostrich; and Klećkowska-Nawrot et al. (2016a) in HG of Capercaillies; they detected acidic mucous secretions in HG of these birds. Also, the positive reaction of PAS reagent was demonstrated in the centrally located cells of glandular epithelium of tubules and acini. Similarly, in domestic duck and native chicken, the glandular secretions of this gland have given positive result to alcian blue $\mathrm{pH} 2.5$, and periodic acid Schiff reagent means that the cells contained both acidic and neutral mucopolysaccharides (Brobby Sr, 1972; Mobini, 2012). In osprey and quail, the HG secretion found mainly neutral mucopolysaccharides (Kozlu et al., 2010; Kozlu \& Altunay, 2011).

Our study revealed that the presence of lymphocytes in the HG of the four avian species but was increased in pigeon and ibis; these cells were distributed in the lobules underneath the lining columnar cell epithelium and in the interstitial connective tissue that was surrounding the acini and tubules. This result was in agreement with those of Schramm (1980).

\section{Conclusion}

In conclusion, the histology and histochemistry of HG were generally similar but not identical in the four avian species, and each species showed characteristic features.
The gland mainly contained both acidic and neutral mucopolysaccharides. This finding showed that the HG has secretory function that plays an important role in lubricating nictitating membrane. Immune cells were observed in the HG of studied birds that increased obviously in case of pigeon and ibis (flying birds), which confirms their role in the immunological reactions.

\section{Abbreviations \\ HG: Harderian gland; LG: Lacrimal gland; CALT: Conjunctiva-associated lymphoid tissue; H\&E: Hematoxylin and eosin; PAS: Periodic acid Schiff}

\section{Acknowledgements}

The authors would like to thank Mr. Khaled, for his technical assistance in this study.

\section{Authors' contributions}

RRB, SAA, MA, and HE participated in the design of the study and collected the samples. RRB was publishing the article "corresponding author". RRB and MA drafted the manuscript. All authors read and approved the final manuscript.

\section{Funding}

This research did not receive any specific grant from funding agencies in the public, commercial, or not-for-profit sector.

Availability of data and materials

No dataset was analyzed in the current study.

Ethics approval and consent to participate Not applicable.

Consent for publication

All authors agree to the publication.

\section{Competing interests}

The authors declare that they have no competing interests.

\section{Author details}

${ }^{1}$ Department of Histology and Cytology, Faculty of Veterinary Medicine, Zagazig University, Zagazig, Sharkia 44511, Egypt. 'Department of Anatomy and Embryology, Faculty of Veterinary Medicine, Zagazig University, Zagazig 44511, Egypt.

Received: 26 March 2020 Accepted: 7 June 2020

Published online: 18 June 2020

\section{References}

Altunay, H., \& Kozlu, T. (2004). The fine structure of the Harderian gland in the ostrich (Struthio camelus). Anatomia, Histologia, Embryologia, 33, 141-145.

Baccari, G. C., Minucci, S., \& Di Matteo, L. (1993). The orbital glands of the terrapin Pseudemys scripta in response to osmotic stress: A light and electron microscope study. Journal of Anatomy, 183(Pt 1), 21-33.

Boydak, M., \& Aydin, M. F. (2009). Histology of the Harderian gland of domestic geese (Anser anser domesticus). Acta Veterinaria Brno, 78, 199-204.

Brobby Sr., G. W. (1972). On the Harderian gland of the domestic duck (Anas platyrhynchus), morphological and histochemical investigations. Zeitschrift für Zellforschung, 133, 223-230.

Burns, R. B. (1974). The Harderian gland in birds. M. Phil Thesis, University of London.

Burns, R. B. (1992). The Harderian gland in birds: Histology and immunology, (pp. 155-163). Berlin Heidelberg: Springer-Verlag.

Burns, R. B., \& Maxwell, M. H. (1979). The structure of the Harderian and lacrimal gland ducts of the turkey, fowl and duck. A light microscope study. Journal of Anatomy, 128(2), 285-292.

Cacho, E. D., Gallego, M., Felices, G., \& Bascuas, J. A. (1991). Myofibroblasts and myoepithelial cells in the chicken Harderian gland. Histology and Histopathology, 6, 303-308. 
Djaridane, Y., Simmonneaux, V., \& Klosen, P. (1999). Immunohistochemical characterization of the epithelial cells of rodent Harderian glands in primary culture. Journal of Anatomy, 195, 523-530.

Fix, A. S., \& Arp, L. H. (1989). Conjunctiva-associated lymphoid tissue (CALT) in normal and Bordetella avium-infected turkeys. Veterinary Pathology, 26, 222-230.

Fix, A. S., Arp, L., \& H. (1991). Particle uptake by conjunctiva-associated lymphoid tissue (CALT) in turkeys. Avian Diseases, 35, 100-106.

Funasaka, N., Yoshioka, M., \& Fujise, Y. (2010). Features of the ocular Harderian gland in the three Balaenopterid species based on anatomical, histological histochemical observations. Mammal Study, 35(1), 9-15.

Ginkel, F. W., Tang, D. C., Gulley, S. C., \& Toro, H. (2009). Induction of mucos Immunity in avian Harderian gland with a replication-deficient Ad5 vector expressing avian influenza $\mathrm{H} 5$ hem agglutinin. Developmental and Comparative Immunology, 33(1), 28-34.

Khan, M. Z. I., Jahan, M. R., Islam, M. N., Haque, Z., Islam, M. R., \& Kon, Y. (2007). Immunoglobulin (lg)-containing plasma cells in Harderian gland in broiler and native chickens of Bangladesh. Tissue and Cell, 39(3), 141-149.

Klećkowska-Nawrot, J., Goździewska-Harłajczuk, K., Barszcz, K., \& Kowalczyk, A. (2015). Morphological studies on the Harderian gland in the ostrich (Struthio camelus domesticus) on the embryonic and postnatal period. Anatomia Histologia and Embryologia 44(2), 146-156.

Klećkowska-Nawrot, J., Goździewska-Harłajczuk, K., Kowalczyk, A. I., Łukaszewicz, E. I., and Nowaczyk, R. I. (2016a). Structural differences of the Harderian gland between common pheasants (Phasianus Colchicus Talischensis) and hybrids of Italian amber and common pheasants. Brazilian Journal of Poultry Science. Revista Brasileira de CiênciaAvícola. ISSN 1516-635X. 18(2), 309-318.

Klećkowska-Nawrot, J., Goździewska-Harłajczuk, K., Kowalczyk, A. I., Łukaszewicz, E. I., and Nowaczyk, R. I. (2016b). Histological, histochemical and ultrastructural studies on Harderian and lacrimal glands of the Capercaillie (Tetrao Urogallus Major L.). Acta Biologica Hungarica, 67, 27-41

Kozlu, T., \& Altunay, H. (2011). Light and electron microscopic studies of the quail (Coturnix coturnix) Harderian gland. Journal of Animal and Veterinary Advances, 10, 932-938.

Kozlu, T., Bozkurt, Y. A., Altunay, H., \& Sari, E. K. (2010). Histological and histochemical studies on the Harderian gland of the osprey (Pandion haliaetus). Journal of Animal and Veterinary Advances, 9, 1875-1879.

Maxwell, M. H., Rothwell, B., \& Burns, R. B. (1986). A fine structural study of the turkey Harderian gland. Journal of Anatomy, 148, 147-157.

Mobini, B. (2012). Histological and histochemical studies on the Harderian gland in native chicken. Veterinary Medicine, 57, 404-409.

Mobini, B. (2014). Histological and histochemical studies on the paraorbital gland in broilers. Journal of Animal Production Advances, 4(11), 527-533. https://doi. org/10.5455/japa.20141122084241.

Nomina Anatomica Veterinaria (2012). 5th edition prepared by the International Committe on Veterinary Gross Anatomical Nomenclature (I.C.V.G.A.N.) and authorized by the General assembly of the World Association of Veterinary Anatomists (W.A.V.A.), konxville, T.N (USA). Published by the Editorial Committee, Hannover, Columbia, Gent and Sapporo. Pp 1-160.

Ohshima, K., \& Hiramatsu, K. (2002). Immunohistochemical localization of three different immunoglobulin classes in the Harderian gland of young chickens. Tissue and Cell, 34, 129-133.

Oliveira, C. A., Telles, L. F., Oliveira, A. G., Kalapathakis, E. G., Oncalves, D. H., \& Mahecha, G. A. (2006). Expression of different classes of immunoglobulin in intraepithelial plasma cells of Harderian gland of domestic ducks Anas Platyrtynches. Veterinary Immunology and Immunopathology, 113(3-4), 257-266.

Payne, A. P. (1994). The Harderian gland: A tercentennial review. Journal of Anatomy, 185, 1-49.

Pradidarcheep, W., Asavapongpatana, S., Mingsakul, T., Poonkhum, R., Nilbunga, S., \& Somana, R. (2003). Microscpic anatomy of the orbital Harderian gland in the common tree shrew (Tupaia glis). Journal of Morphology, 255(3), 328-336.

Rehorek, S. J., Baker, J. J., Hutchinson, M. N., Bruce, T., \& F. (2006). The Harderian gland of two species of skink (Tiliqua rugosa and Hemiergis decresiensis): A discussion of the significance of lymphatic tissue in the squamate Harderian gland. Canadian Journal of Zoology, 84, 706-714.

Sakai, T. (1981). The mammalian Harderian gland: Morphology, biochemistry, function and phylogeny. Archivum Histologicum Japonicum, 44, 299-333.

Schramm, U. (1980). Lymphoid cells in the Harderian gland of birds An Electron microscopical study. Cell and Tissue Research, 205(1), 85-94. 169.

Shirama, K., Satoh, T., Kitamura, T., \& Yamada, J. (1996). The avian Harderian gland: Morphology and immunology. Microscopy Research and Technique, 34, 16-27.
Suvarna, K. S., Layton, C., and Bancroft, J. D. (2018). Bancroft's theory and practice of histological techniques e-book. Elsevier Health Sciences.

Wight, P. A., Mackenzie, G. M., Rothwell, B., \& Burns, R. B. (1971a). The Harderian gland of domestic fowl. II-Histochemistry. Journal of Anatomy, 110(3), 323-333.

Wight, P. A., Burns, R. B., Rothwell, B., \& Mackenzie, G. M. (1971b). The Harderian gland of domestic fowl. 1-Histology, with reference to genesis of plasma Cells and Russell bodies. Journal of Anatomy, 110(2), 307-315.

Zakeri, A., \& Kashefi, P. (2011). The comparative effects of five growth promoters on broiler chickens humoral immunity and performance. Journal of Animal and Veterinary Advances, 10(9), 1097-1101.

\section{Publisher's Note}

Springer Nature remains neutral with regard to jurisdictional claims in published maps and institutional affiliations.

\section{Submit your manuscript to a SpringerOpen ${ }^{\circ}$ journal and benefit from:}

- Convenient online submission

- Rigorous peer review

- Open access: articles freely available online

- High visibility within the field

- Retaining the copyright to your article

Submit your next manuscript at $\boldsymbol{\nabla}$ springeropen.com 